Artikel Konseptual

\title{
RELEVANSI NILAI-NILAI PERJUANGAN KH. MASJKUR DALAM PEMBELAJARAN SEJARAH BERBASIS PENDIDIKAN KARAKTER BAGI SISWA MA DI MALANG
}

\author{
Lutfiah Ayundasari \\ lutfiah.fis@um.ac.id \\ Jurusan Sejarah, Universitas Negeri Malang
}

\begin{abstract}
Learning history is one of way to educated student with morality due to this subject have important factor to built citizen's character, national civilization, and sense of nationalism. Character education could be done by integrate local history matter to learning history. This intelectual engagement hopefully can encourage students to love history subject while making it easier to grow their positive character through using role model which is close with their real life. In this article local resident who was used as role model is KH. Masjkur. He is a person come from Malang who admired for great acts to Indonesia. He has proved his exsistence in national level for eduation, military, and politic during three periods from National Revolution to The New Order.
\end{abstract}

Key words: KH. Masjkur, learning history, character education

\section{PENDAHULUAN}

Secara teoritis pembelajaran sejarah mengandung nilai-nilai luhur yang diperlukan dalam pergaulan bermasyarakat dan berbangsa. Oleh karena itu, pesan pembelajaran ini sejalan dengan amanat kurikulum yang menginginkan pendidikan karakter bagi para siswa. Dalam Kurikulum 2013 terdapat 18 karakter yang harus ditanamkan, tentu saja semua karakter tersebut tidak dapat diintegrasikan hanya dalam satu kompetensi dasar. Jauh sebelum pembelajaran dilaksanakan guru harus membuat perencanaan mulai dari program tahunan, program semester, sebaran materi dalam silabus dan RPP. Dalam proses perencanaan inilah guru dapat memilah dan memilih jenis-jenis karakter yang sesuai dengan kompetensi dasar yang mereka ajarkan. Urgensi penanaman karakter ini sesuai dengan tugas utama pendidikan yang tidak hanya menuangkan sejumlah informasi, tetapi juga mengusahakan agar konsep-konsep tertanam kuat dalam benak siswa (Hatimah, 2009: 1). Konsep yang dimaksud tidak terbatas pada materi ajar tetapi juga konsep tentang nilai-nilai yang harus diikuti oleh siswa.

Dewasa ini karakter menjadi sesuatu yang sangat penting, tanpa hal tersebut maka generasi muda Indonesia akan dengan mudah kehilangan identitas kebangsaan seiring 
dengan semakin cepatnya laju globalisasi. Penanaman karakter ini menjadi sangat menantang jika disampaikan kepada remaja yang sedang dalam proses pencarian identitas. Seringkali guru merasa kesulitan menghadapi siswa-siswa SMA, mereka cenderung mudah berontak terhadap apa yang dirasa tidak sesuai termasuk dalam kegiatan pembelajaran. Namun penanaman karakter ini harus tetap dilaksanakan karena moral merupakan suatu kebutuhan penting bagi remaja, terutama sebagai pedoman menemukan identitas dirinya, mengembangkan hubungan personal yang harmonis, dan menghindari konflikkonflik perang yang selalu terjadi dalam masa transisi (Desmita, 2006:206).

Untuk menghindari masalah tersebut maka kegiatan ini harus dikemas sedemikian rupa agar siswa merasa bahwa apa yang mereka pelajari benar-benar dibutuhkan dalam kehidupan nyata. Pendidikan karakter ini dapat disampaikan dengan metode langsung atau tidak langsung. Metode langsung mulai dengan penentuan perilaku yang dinilai baik, sebagai upaya indoktrinasi berbagai ajaran. Caranya dengan memusatkan perhatian secara langsung pada ajaran tersebut lewat mendiskusikan, mengilustrasikan, menghafalkan dan mengucapkannya. Sedangkan metode tidak langsung dapat dilakukan dengan menciptakan situasi yang memungkinkan perilaku yang baik dapat dipraktikkan (Zuchdi, D. 2008:5). Dalam artikel ini akan diulas tentang pendidikan karakter yang disampaikan secara langsung dengan mengeksloprasi dan mendiskusikan nilai-nilai yang dimiliki oleh tokoh lokal dan relevan dengan matapelajaran sejarah pada Kurikulum 2013.

Tokoh yang akan dikaji dalam artikel ini adalah $\mathrm{KH}$. Masjkur, beliau merupakan pejuang asal Malang yang memiliki peran dalam merintis, mempertahankan dan mengisi kemerdekaan Indonesia. Meskipun hanya menyandang gelar sebagai santri beliau mampu membuktikan diri untuk aktif dalam bidang pendidikan, militer dan politik. Secara umum masyarakat Malang kurang mengetahui tentang tokoh tersebut dan perjuangannya, meskipun beliau termasuk tokoh nasional. Oleh karena itu, penulis menganggap bahwa pengenalan tokoh ini melalui pembelajaran sejarah di sekolah merupakan salah satu langkah penting untuk mendekatkan siswa dengan kajian sejarah lokal. Selain itu secara prosedural terdapat ruang untuk mengenalkan tokoh lokal dalam kegiatan pembelajaran yaitu dengan mengintegrasikannya pada standar kompetensi 3.7 matapelajaran Sejarah Peminatan kelas XI Kurikulum 2013.

Kajian tersebut juga relevan dengan pendidikan karakter bagi siswa karena nilainilai yang dimiliki oleh $\mathrm{KH}$. Masjkur merupakan bagian dari 18 karakter yang harus ditanamkan kepada siswa. Selain itu, karakter yang dimiliki KH. Masjkur sejalan dengan pendapat S.K. Kochar (2008:27-37) yang menyatakan bahwa pembelajaran sejarah memiliki 14 sasaran umum beberapa di antaranya merupakan pembelajaran karakter yaitu 
toleransi, orientasi masa depan, nasionalisme dan keterampilan yang berguna. Mengingat bahwa tokoh ini berlatar belakang pendidikan agama Islam maka akan sangat sesuai jika penyampaian materi dilakukan pada siswa madrasah aliyah. Kegiatan ini diharapkan mampu menumbuhkan kepekaan terhadap sejarah lokal dan menjadikan tokoh tersebut sebagai inspirasi perjuangan mereka dalam belajar dan meraih cita-cita.

\section{BIOGRAFI SINGKAT KH. MASJKUR}

KH. Masjkur merupakan salah satu ulama" kelahiran Malang yang memiliki peran cukup penting dalam sejarah Indonesia baik di bidang politik, militer dan pendidikan. Beliau merupakan putera pertama dari KH.Maksum dan Hj. Maemunah. Meskipun lahir dalam masa penjajahan Belanda, secara ekonomi kehidupan keluarga KH. Masjkur cukup mapan karena profesi ayahnya sebagai pedagang besar. Hal ini dibuktikan dengan kemampuan KH. Maksum untuk menunaikan ibadah haji beberapa kali bersama anggota keluarganya termasuk $\mathrm{KH}$. Masjkur. Pada usia 10 tahun beliau berangkat haji bersama ayah dan bibinya. Kemapanan ini juga berdampak pada kesempatan pendidikan yang dapat beliau nikmati sebagai seorang santri di berbagai pesantren di Jawa.

Di daerah kelahiran KH. Masjkur yaitu Singosari terdapat pesantren yang cukup dihormati yaitu Pesantren Bungkuk. Sebuah pesantren yang dirintis oleh Mbah Yai Hamimudin pada tahun 1870 yang menurut tradisi lisan merupakan pasukan dari Pangeran Diponegoro. Pesantren ini mencapai puncak ketenarannya pada masa kepemimpinan $\mathrm{KH}$. Muhammad Thohir, salah seorang menantu Mbah Hamimuddin. Di pesantren inilah KH. Masjkur mengawali rekam jejak sebagai santri untuk belajar qiraatul Qur'an, gramatika bahasa Arab (nahwu, sharaf dII) dan kitab-kitab dasar lainnya (Soebagijo, 1982: 6). Setelah menamatkan pembelajaran di pesantren ini KH. Masjkur melanjutkan ke Pesantren Sono di Buduran Sidoarjo untuk memperdalam ilmu gramatika bahasa Arab selama empat tahun. Tata bahasa Arab merupakan ilmu penting yang harus dikuasai oleh para santri sebagai dasar kajian terhadap Al-Qur'an, hadist, maupun kitab-kitab ulama' abad pertengahan. Selepas memahami dengan detail ilmu tata bahasa KH. Masjkur mendalami ilmu fiqih di Pesantren Siwalan Panji Sidoarjo. Pesantren ini berdiri sejak abad XVIII dan merupakan tempat belajar ulama"-ulama" besar di Jawa Timur.

Pesantren Tebuireng merupakan tujuan $\mathrm{KH}$. Masjkur berikutnya untuk memperdalam Ilmu Tafsir dan IImu Hadits. Pengasuh pesantren ini yaitu KH. Hasyim Asyari memang terkenal ahli dalam penguasaan kedua ilmu tersebut. Lulus dari Tebuireng, KH.

JPSI, Vol. 1, No., 1, 2018 
Masjkur menuju Pesantren Kademangan Bangkalan pimpinan KH. Kholil untuk memperdalam Ilmu Qiraatul Qur'an dan tata bahasa Arab selama satu tahun. Selanjutnya beliau menuju Pesantren Jamsaren Solo. Ketika berada di pesantren ini KH. Masjkur sempat bersekolah di Madrasah Manbaul Ulum, sebuah sekolah Islam modern pertama yang diakui oleh Gubernur Jendral Hindia Belanda pada tahun 1906. Di madrasah ini tidak hanya diajarkan ilmu agama tetapi juga ilmu umum dengan persentase $30 \%$ sampai $40 \%$ ilmu agama dan $60 \%$ sampai $70 \%$ ilmu umum untuk tingkat dasar sedangkan untuk tingkat menengah $100 \%$ diajarkan ilmu agama (Hisyam,2001:144). Di pesantren ini KH. Masjkur menyelesaikan pendidikannya sampai kelas 9 dan diangkat sebagai guru bantu sebelum melanjutkan safari pesantren ke Jawa Barat. Selama di Solo beliau juga belajar Bahasa Belanda kepada seorang wanita Indo.

Setelah belasan tahun belajar di berbagai pesantren di Jawa, KH. Masjkur kembali ke Singosari dan menikah dengan cucu KH. Muhammad Tohir (pengasuh Pesantren Bungkuk). Tidak lama berselang setelah kedatangannya, KH. Maksum meninggal sehingga beliau harus mengambil alih pengelolaan usaha milik ayahnya. Ternyata kemampuan bisnis beliau cukup baik, selain melanjutkan usaha perdagangan kain milik ayahnya beliau juga membangun beberapa usaha lain yaitu pembuatan kecap yang dilakukan di rumahnya sendiri, ternak sapi dan produksi susu sapi dilakukan di dekat rumahnya, pembuatan krupuk, industri rumahan gula merah yang terbuat dari tebu. Usaha pembuatan gula ini dilakukan di daerah Karangploso di dekat perkebunan tebu yang dimilikinya sendiri. Penggilingan gula merah ini dilakukan secara tradisional dengan menggunakan tenaga hewan (Ayundasari, 2018:24). Dari usaha inilah kelak beliau membiayai pendirian sekolah Islam formal pertama di Malang yaitu Misbachul Watan.

Selain sebagai pengusaha dan guru, KH. Masjur juga turut aktif di komunitas diskusi Taswirul Afkar dan Nahdlatul Ulama'. Pada masa Jepang beliau tercatat sebagai salah satu pendiri PETA, anggota Syu Sangi Kai dan anggota BPUPK. Keterlibatan beliau dalam bidang militer dan politik terus berlanjut, pada masa revolusi fisik beliau adalah pimpinan Lasykar Sabilillah dan ikut dalam perang gerilya. KH. Masjkur juga merupakan Menteri Agama Indoensia dalam beberapa kabinet masa Demokrasi Liberal dan angota DPR RI masa Orde Baru. Di bidang pendidikan beliau merupakan salah satu Dewan Kurator PTIQ Jakarta, anggota dari dewan pendiri UII Yogyakarta, Ketua Yayasan Unisma dan Almaarif Malang. Selain itu juga menjabat sebagai anggota Dewan Mustasyar PBNU sampai akhir hayatnya.

JPSI, Vol. 1, No., 1, 2018 


\section{KH. MASJKUR: PERJUANGAN LINTAS TIGA JAMAN}

KH. Masjkur merupakan ulama' asal Malang yang berkiprah di tiga jaman yaitu masa penjajahan, Orde Lama dan Orde Baru. Meskipun tidak memiliki ijazah pendidikan formal KH. Masjkur telah memberikan bukti bahwa santri dapat ikut berperan dalam memperjuangkan, mempertahankan dan mengisi kemerdekaan sesuai dengan kapasitas yang dimiliki. Kiprah KH. Masjkur dalam memperjuangkan kemerdekaan dimulai dengan mendirikan sekolah Islam formal pertama yang diberi nama Misbachul Watan. Arti nama tersebut adalah pelita tanah air, sebuah harapan yang disematkan pada sekolah yang beliau dirikan agar kelak para siswa dapat menjadi penerang bagi masa depan yang lebih baik yaitu kemerdekaan.

Ide KH. Masjkur tentang kemerdekaan pada tahun 1920-an yang diwujudkan dengan mendirikan sebuah sekolah merupakan pengaruh tidak langsung dari pelajaranpelajaran yang telah beliau terima di berbagai pesantren yang pernah disinggahi. Selain itu juga merupakan cerminan pemikiran dari guru-guru beliau. Pada masa tersebut kalangan pesantren mengenal istilah isykariman au mut syahidan, ungkapan yang memberikan pilihan hidup mulia atau mati syahid. Hal ini berarti mereka memiliki dua pilihan hidup mulia yang diperjuangkan atau mati syahid saat dalam perjuangan tersebut. Sehingga dapat disimpulkan bahwa kelompok pesantren saat itu bersikap non-kooperatif terhadap pemerintah kolonial dan telah memiliki bibit-bibit nasionalisme. KH. Masjkur memilih jalan pertama yakni meraih kemuliaan hidup dengan mengajak masyarakat untuk belajar sesuai dengan perkembangan jaman.

Misbachul Watan didirikan pada saat pendidikan Islam ala Barat belum populer. Pada saat itu umat muslim hanya mempercayakan pendidikan anak-anak mereka kepada pesantren dengan materi yang terbatas pada ilmu agama, bahkan tidak ada pelajaran baca tulis latin. Pada awal pendiriannya tahun 1923, sekolah ini tidak hanya mendapatkan tekanan dari wedana sebagai dampak dari pemberlakuan Ordonansi Sekolah Liar, tetapi juga mendapat penolakan dari para kiai. Mereka menganggap bahwa belajar di sekolah formal yang menggunakan sistem Barat menyerupai orang kafir. Namun, kedua masalah ini dapat diredam dengan datangnya $\mathrm{KH}$. Wahab Chasbullah ke Singosari yang menyatakan bahwa Misbachul Watan merupakan bagian dari Nahdlatul Watan Surabaya. Sehingga wedana tidak perlu khawatir tentang materi ajar di sekolah tersebut, begitupun dengan para kiai yang akhirnya mafhum dan menerima bentuk baru pembelajaran bagi masyarakat di sekitar Singosari.

Perjuangan dan peran KH. Masjkur tidak berhenti sampai dengan berdirinya Misbachul Watan, karena seiring dengan perkembangan jaman sekolah ini terus beradaptasi 
dan berubah nama menjadi Yayasan Pendidikan Almaarif pada tahun 1978 yang sampai saat ini memiliki delapan jenis sekolah dengan ribuan siswa setiap tahunnya. Peran beliau dalam bidang pendidikan tidak hanya di Malang tetapi di tingkat nasional yaitu sebagai Dewan Kurator Perguruan Tinggi Ilmu AL-Qur'an Jakarta, terlibat sebagai anggota Panitia Perencanaan Pendirian STI (UII Yogyakarta) dari perwakilan PBNU, dan merupakan pendiri sekaligus ketua Yayasan Universitas Islam Malang. Semua perguruan tinggi tersebut masih terus berkembang dan menjadi tujuan bagi pelajar di seluruh Nusantara untuk memperdalam ilmu-ilmu keislaman.

Selain berkiprah di bidang pendidikan KH. Masjkur juga aktif dalam kegiatan militer sejak sebelum kemerdekaan. Keikutsertaan beliau dalam organisasi kemiliteran pertama kali pada saat tergabung di PETA (Pembela Tanah Air) bersama KH. Wachid Hasyim, Abikoesno Tjokrosoejoso dan Soeroso. Beliau juga ikut mendirikan organisasi militer Hizbullah Shoedantjo pada tahun 1944 bersama KH. Wachid Hasyim dan KH. Wahab Chasbullah. Kemudian pada tahun 1945 KH. Masjkur membentuk Barisan Sabilillah di seluruh Indonesia, beliau sekaligus sebagai panglimanya. Lasykar Sabilillah merupakan teritorial organ tentara Hizbullah di daerah-daerah yang berpusat di Malang. Lasykar ini tetap aktif bahkan sampai masa revolusi fisik. (Ayundasari, 2018: 27). Sebagai bentuk penghormatan terhadap KH. Masjkur dan para pejuang lasykar tersebut di Malang didirikan monumen yang berupa masjid yaitu Masjid Hizbullah di Singosari dan Masjid Sabilillah di Blimbing.

Peran politik KH. Maskjur dimulai dengan keikutsertaan beliau sebagai anggota Syu Sangi Kai di Malang. Beliau bertugas menghimpun informasi tentang keluhan rakyat pada masa Jepang. Selain itu beliau juga menjadi ketua Masyumi cabang Malang. Pada masa ini tidak banyak tokoh daerah yang dianggap memiliki kompetensi di bidang politik, hal ini terkait dengan tingkat pendidikan rakyat Indonesia yang masih sangat rendah. Namun, tidak dengan $\mathrm{KH}$. Masjkur, beliau mendapatkan banyak kesempatan pendidikan pesantren dan memiliki kemampuan baca tulis hitung serta sedikit bahasa Belanda sehingga ketika pemerintah Jepang menarik simpati rakyat Indonesia dengan merealisasikan Janji Koiso berupa pendirian Badan Penyelidik Usaha Kemerdekaan Indonesia beliau menjadi salah satu anggotanya sebagai perwakilan dari Ketua BPP Cabang Malang dan Masyumi.

Sebagai salah satu anggota BPUPK KH. Masjkur turut serta dalam sidang-sidang penyusunan dasar negara Indonesia. Tidak dapat dipungkiri bahwa pada sidang-sidang tersebut terdapat pertentangan tentang bagaimana bentuk dasar negara dan kelompok Islam termasuk beliau menginginkan dasar negara berlandaskan agama Islam. Namun, hal tersebut adalah proses menuju tercapainya kesepakatan bersama demi berdirinya 
sebuah negara yang menghargai keberagaman. Pada akhirnya semua komponen perwakilan masyarakat Indonesia bersepakat bahwa dasar negara adalah Pancasila yang berlandaskan keTuhanan Yang Maha Esa, termasuk KH. Masjkur. Kelak pada masa pemerintahan Orde Baru Pancasila diterapkan sebagai asas tunggal bagi semua organisasi di Indonesia.

Peran politik KH. Masjkur pasca kemerdekaan adalah sebagai anggota KNIP dan Dewan Pertahanan Negara. Selain itu beliau pernah menjabat sebagai menteri agama selama empat periode kepemimpinan perdana menteri pada masa Demokrasi Liberal yaitu antara tahun 1947 sampai 1955. Selama menjabat menteri agama sampai pada masa gerilya kebijakan penting yang diambil $\mathrm{KH}$. Masjkur dalam bidang pendidikan yaitu dengan mengeluarkan Peraturan Menteri Agama No.2/1948 tentang bantuan kepada perguruan agama (Azra dan Umam,1998:67). KH. Masjkur adalah salah seorang menteri yang lolos dari sergapan Belanda ketika telah menguasai Yogyakarta pada Agresi Militer II. Ketika Presiden dan Wakil Presiden ditawan Belanda, maka dibentuklah PDRI (Pemerintah Darurat Republik Indonesia). Dalam masa ini KH. Masjkur duduk sebagai anggota Komisariat PDRI di Jawa bersama Soesanto Tirtoprodjo, IJ. Kasimo dan Panji Suroso.

Pasca pemilu pertama Indonesia tahun $1955 \mathrm{KH}$. Masjkur terpilih menjadi anggota DPR RI dari Partai Nahdlatul Ulama'. Jabatan sebagai anggota legislatif terus diemban oleh KH. Masjkur sampai tahun 1982. Selain itu beliau juga menjadi anggota Dewan Pertimbangan Agung pada masa Orde Baru. Setelah tahun 1983 beliau meninggalkan jabatan politik dan lebih fokus pada kegiatan sosial melalui organisasi Nahdlatul Ulama' serta mengelola lembaga pendidikan yang telah beliau dirikan seperti Yayasan Pendidikan Almaarif dan Universitas Islam Malang. Semua kegiatan tersebut beliau lakukan sampai menjelang wafat pada tahun 1992. Perjuangan panjang beliau selama tiga jaman tetap dapat dinikmati hingga kini, seorang santri tanpa latar belakang pendidikan formal dan berasal dari daerah terpencil tetap dapat berkarya bagi bangsa sesuai kapasitasnya. Nilainilai perjuangan beliau layak untuk diulas kembali dalam pembelajaran sejarah lokal terutama bagi siswa-siswi di Malang.

\section{RELEVANSI NILAI-NILAI PERJUANGAN KH. MASJKUR DALAM PEMBELAJA- RAN SEJARAH}

Pada dasarnya dalam Sejarah Nasional Indonesia sudah terekam nama-nama tokoh daerah yang turut dalam memperjuangkan, mempertahankan dan mengisi kemerdekaan 
hanya saja porsi kajian mereka dalam konteks ini cukup kecil. Oleh karena itu, akan lebih baik jika peran tokoh-tokoh daerah ini dikaji dalam sejarah lokal dan disampaikan melalui pembelajaran sejarah sebagai upaya untuk mendekatkan pelajaran sejarah dengan lingkungan siswa. Dewasa ini melalui Kurikulum 2013 pemerintah telah memberikan kesempatan cukup luas bagi guru untuk melakukan improvisasi pembelajaran termasuk dalam pembelajaran sejarah.

Pada Kurikulum 2013 matapelajaran sejarah terbagi menjadi dua yaitu Sejarah Wajib dan Sejarah Peminatan. Perbedaan di antara keduanya adalah tingkat kedalaman dan keluasan materi serta sasaran pembelajaran (siswa). Jumlah jam pelajaran yang cukup banyak memungkinkan guru sejarah untuk memvariasikan materi yang mereka ajarkan. Sebelum pemberlakuan kurikulum ini seringkali dikeluhkan bahwa jumlah jam matapelajaran sejarah terbatas sedangkan materi yang disampaikan cukup luas. Salah satu bentuk variasi materi tersebut adalah mengulas peran tokoh-tokoh lokal dalam sejarah Indonesia. Dalam konteks sejarah lokal di Malang ada banyak tokoh yang dapat dikenalkan kepada para siswa melalui pembelajaran sejarah yang sesuai dengan kompetensi dasar dalam kurikulum.

Kajian tentang perjuangan KH. Masjkur dapat diintegrasikan pada kompetensi dasar 3.7 kelas XI Sejarah Peminatan tentang respon bangsa Indonesia terhadap imperialisme dan kolonialisme dalam bidang politik (organisasi pergerakan), ekonomi (bentuk perlawanan terhadap praktik monopoli), sosial-budaya (karya seni dan sastra), dan pendidikan (Taman Siswa, Kayu Tanam). Materi yang dapat dikaji antara lain adalah respon masyarakat Islam Malang atas kebijakan pendidikan pemerintah kolonial terhadap Bumiputera yang dalam hal ini terwakili oleh inisiatif KH. Masjkur dalam mendirikan sekolah Islam formal pertama di Malang. Selain itu materi ini juga sarat akan nilai-nilai perjuangan yang sesuai dengan isu pembelajaran karakter di sekolah. Nilai-nilai perjuangan $\mathrm{KH}$. Masjkur yang dapat dijadikan role model bagi para siswa antara lain;

\section{Visioner dan Pantang Menyerah}

Pandangan KH. Masjkur yang visioner tercermin dalam idenya untuk mendirikan sekolah formal Islam di tengah masyarakat yang masih berpandangan tradisional. Pada tahun 1923 ketika beliau mendirikan madrasah Misbachul Watan masyarakat Islam Singosari termasuk para kiai berpendapat bahwa tindakan itu menyerupai penjajah sehingga tidak boleh dilakukan. Sedangkan KH. Masjkur yang juga memiliki latar belakang pendidikan sebagai santri merasa bahwa pendidikan agama tidak cukup sebagai bekal untuk melawan penjajah dan meraih kemuliaan hidup (merdeka). Oleh karena itu, diperlukan inovasi pendidikan dengan mengakomodir kemampuan seperti baca tulis latin dan ilmu 
umum. Kedua hal ini sebagai bekal untuk memahami posisi bangsa Indonesia dalam rangka meraih kehidupan yang lebih baik.

Pada dasarnya pandangan visioner $\mathrm{KH}$. Masjkur tentang pendidikan tidak terlepas dari prinsip yang dianut oleh kelompok pesantren yaitu Al Muhafadlatul alal qadimish shalih wal akhdzu bil jadidil ashlah yaitu memelihara nilai-nilai lama yang baik dan mengambil nilai-nilai baru yang lebih baik (Mas'ud, 2006:255). Prinsip ini mencerminkan sikap keterbukaan terhadap hal-hal baru yang memiliki nilai-nilai lebih baik sesuai dengan perkembangan jaman tanpa meninggalkan nilai-nilai luhur yang telah dianut. Kombinasi antara dua hal tersebut membentuk lembaga pendidikan baru yaitu madrasah, sebuah lembaga pendidikan Islam yang bersifat klasikal dengan materi ajar ilmu agama dan ilmu umum. Melalui lembaga ini kelompok Islam tradisional bertransformasi menjadi kelompok yang mampu berdiri di dua ranah, ahli dalam keilmuan Islam dan memiliki kemampuan dalam ilmu umum seperti ekonomi, politik dan budaya.

Pandangan yang visioner dan kemampuan memilah nilai baru tanpa meninggalkan nilai lama yang baik merupakan salah satu jenis karakter yang perlu ditanamkan kepada siswa. Apalagi dewasa ini perkembangan teknologi informasi semakin tidak terbendung, derasnya arus informasi harus disikapi dengan bijaksana. Jika siswa tidak memiliki keterampilan tersebut, maka mereka akan mudah terbawa arus informasi yang kadang masih perlu dicek ulang kebenaran dan kesesuaiannya dengan kepribadian bangsa. Melalui contoh kehidupan $\mathrm{KH}$. Masjkur diharapkan siswa dapat memahami bahwa sejalan dengan perkembangan jaman harus ada aspek-aspek dalam kehidupan yang perlu diperbaharui tanpa meninggalkan nilai-nilai lama yang baik.

Siswa-siswa yang sedang bersekolah saat ini merupakan generasi yang lahir dalam rentang tahun 1995 sampai 2010. Para sosiolog menyebut mereka sebagai Generasi Z atau dikenal juga sebagai Generasi Strawberry yang indah diluar namun mudah rapuh, hancur, sakit hati, kecewa dan putus asa. Pada titik kelemahan inilah kisah-kisah perjuangan tokoh lokal yang pantang menyerah perlu disajikan dalam pembelajaran. Dalam konteks kehidupan KH. Masjkur contoh perjuangan beliau yang pantang menyerah yaitu perjuangan untuk mendirikan Madrasah Misbachul Watan secara swadaya demi terdidiknya kaum muslim di tengah tekanan pemerintah Belanda dan penolakan para kiai. Selain itu juga perjalanan beliau selama gerilya bersama putra tunggal beliau yang masih kecil mulai dari Yogyakarta-Solo-Ponorogo-Trenggalek-Gandusari-Panggul-Dongko-KampakTremas-Yogyakarta sejak Desember 1948 sampai Maret 1949 dalam rangka mempertahankan kemerdekaan. Contoh-contoh tersebut diharapkan dapat menjadi inspirasi bahwa tidak ada satupun kesuksesan tanpa perjuangan dan kehidupan mereka saat ini 
jauh lebih mudah daripada kehidupan para pejuang. Sehingga tidak seharusnya jika mereka mudah putus asa dan menyerah hanya karena hal-hal sepele.

\section{Religius dan Toleran}

Sikap KH. Masjkur lainnya yang dapat dijadikan teladan dan relevan dengan karakter yang diharapkan dalam Kurikulum 2013 adalah religius dan toleran. Dewasa ini banyak bermunculan kelompok-kelompok kajian agama baik secara offline maupun online. Pada dasarnya tidak ada yang salah dengan hal tersebut bahkan bisa jadi fenomena ini merupakan indikator semakin religiusnya umat Islam di Indonesia. Namun, yang perlu ditekankan adalah semakin meningkatknya intensitas dan kualitas hubungan antara manusia dengan Allah bukan berarti mencederai kualitas hubungan antara manusia dengan manusia. Sedangkan yang terjadi saat ini seringkali sebaliknya, orang-orang yang sudah merasa sangat beriman menjadi eksklusif dan mudah menjustifikasi orang lain bertindak tidak sesuai dengan ajaran Islam. Padahal jika kita telusuri lebih jauh orang-orang yang sangat memahami hukum-hukum agama cenderung lebih moderat dalam menyikapi masalah yang berkaitan dengan hubungan horisontal.

$\mathrm{KH}$. Masjkur merupakan seorang santri kelana yang telah belajar di berbagai pesantren selama belasan tahun. Sikap religius beliau tidak perlu diragukan lagi meskipun beliau bukan seorang pimpinan pondok pesantren. Hal yang perlu dijadikan contoh dari beliau adalah bahwa setiap umat Islam wajib belajar ilmu agama dan menerapkannya dalam kehidupan sehari-hari, namun kemampuan tersebut tidak seharusnya menjadi batas interaksi dengan kelompok-kelompok umat Islam lain atau bahkan kelompok nonMuslim. Semakin paham ilmu agama bukan berarti semakin radikal dan mudah menghakimi amalan orang lain, karena kita hidup dalam masyarakat yang beragam. Selain itu, kemerdekaan Indonesia tidak hanya diraih oleh kelompok tertentu sehingga seharusnya semua umat Islam bersikap toleran terhadap perbedaan ini. Tumbuhnya sikap religius dan toleran memang merupakan proses yang panjang, dalam konteks inilah mengulas kembali perjalanan KH. Masjkur dalam penerimaannya terhadap Pancasila sebagai dasar negara merupakan hal yang penting disajikan untuk para siswa agar mereka dapat mengambil hikmah dari rangkaian peristiwa dengan kesimpulan bahwa keimanan dan pemahaman ilmu agama bukan alasan untuk bersikap ekslusif dan tidak toleran dalam kehidupan sosial.

\section{Cinta tanah air}

Sikap cinta tanah air yang dimiliki KH. Masjkur ditunjukkan melalui pendirian Madrasah Misbachul Watan. Madrasah ini diharapkan mampu menghasilkan pelajar-pelajar 
yang dapat menjadi pelita bagi tanah air Indonesia menuju kehidupan yang lebih baik yaitu lepas dari penjajahan Belanda. Selain itu, kecintaan KH. Masjkur terhadap Indonesia juga tercermin dalam semangat beliau untuk turut serta dalam PETA pada masa Jepang, Hizbullah dan Sabilillah masa perjuangan kemerdekaan serta perang gerilya pada masa mempertahankan kemerdekaan. Semangat nasionalisme diperoleh beliau melalui kegiatan belajar di pesantren, pengamatan lingkungan sekitar, maupun kelompok-kelompok diskusi di kalangan para santri. Nasionalisme di kalangan komunitas pesantren tumbuh sebagai bentuk kesadaran memiliki bangsa dan sentimen anti penjajahan. Salah satu tokoh ulama' yang mengajarkan tentang hal ini adalah Syekh Nawawi al-Banteni, beliau merupakan guru dari KH. Kholil Bangkalan dan KH. Hasyim Asy'ari Jombang. Dua tokoh terakhir adalah pemilik pesantren besar di Jawa yang mana para santrinya merupakan bagian dari tokoh-tokoh pejuang kemerdekaan Indonesia termasuk KH. Masjkur.

Semboyan komunitas pesantren dalam melawan pemerintah kolonial adalah Isykariman au mut syahidan yang berarti hidup terhormat atau mati syahid. Dalam hal ini para kiai memiliki otoritas untuk memberikan fatwa bahwa mempertahankan tanah air adalah kewajiban bagi setiap mukmin. Lebih dari itu mengusir penjajah diidentikkan dengan menolak bahaya, sebuah konsep hukum yang berkembang di kalangan santri. Landasan ideologi ini telah sedemikian familiar di kalangan muslim Jawa, yang mayoritas adalah penganut madzhab Syafi'i. Beberapa karya yang ditulis oleh ulama' Syafi'i terkemuka seperti Al-Ghazali dan Al-Bajuri dan digunakan secara luas oleh ulama' dan santri Jawa, membenarkan bahwa amar makruf merupakan fardhu kifayah dan dipandang sama pentingnya dengan jihad, berjuang atau bertempur sebagai kewajiban agama (Mas'ud, 2006:84).

\section{Kerja keras}

Kerja keras merupakan salah satu karakter yang dikembangkan dalam Kurikulum 2013, melalui pembelajaran sikap ini diharapkan siswa mampu bersungguh-sungguh dalam mengatasi berbagai hambatan belajar dan tugas serta mampu menyelesaikan tugas dengan sebaik-baiknya. Penanaman sikap ini pada siswa madrasah aliyah dapat dilakukan dengan menggunakan contoh kehidupan para kiai termasuk $\mathrm{KH}$. Masjur yang merupakan tokoh lokal Malang. Kerja keras beliau selama masa hidupnya di berbagai jaman dapat dijadikan inspirasi sekaligus materi sejarah lokal, agar siswa juga lebih memahami keikutsertaan warga Malang dalam upaya mencapai, mempertahankan dan mengisi kemerdekaan.

Sejak kecil KH. Masjkur diajari untuk senantiasa bekerja keras oleh ayahnya, sebagai anak laki-laki pertama beliau harus menjadi teladan sekaligus bertanggungjawab kepada 
adik-adiknya. Hal ini tercermin dalam beberapa peristiwa yaitu; pertama, keikutsertaan beliau berdagang di Surabaya semasa kecil; kedua, kehidupan selama menjadi santri kelana selama belasan tahun menuntut kerja keras dalam belajar dan beradaptasi dengan berbagai jenis lingkungan baru, tanpa keterampilan ini sulit bagi seorang santri untuk bertahan; ketiga, menjadi tulang punggung keluarga tidak lama setelah kepulangan beliau dari pesantren karena ayahnya meninggal; keempat, kerja keras dalam merintis berbagai usaha antara lain pembuatan kecap, ternak sapi, produksi susu, pabrik kerupuk dan gula merah; kelima, kerja keras dalam merintis dan mempertahankan madrasah yang beliau dirikan sejak tahun 1923 dan tetap beliau kelola sampai menjelang akhir hayatnya tahun 1992.

\section{SIMPULAN}

Kesempatan untuk mengeksplorasi materi pembelajaran sejarah yang disediakan oleh Kurikulum 2013 selayaknya dimanfaatkan dengan maksimal oleh guru untuk memperkaya kajian sejarah di sekolah khususnya sejarah lokal. Kedekatan intelektual yang dibangun melalui kajian sejarah lokal diharapkan mampu menumbuhkan kecintaan siswa terhadap sejarah. Selain itu, melalui contoh-contoh nyata perjuangan tokoh lokal dengan sikap mereka yang patriotis, nasionalis, dan agamis diharapkan mampu memperkuat penanaman karakter sesuai tujuan kurikulum. Dalam konteks kajian ini perjuangan KH. Masjkur dalam merintis, mempertahankan dan mengisi kemerdekaan layak untuk dijadikan bagian dari kajian sejarah lokal Malang yang diintegrasikan pada standar kompetensi 3.7 Sejarah Peminatan kelas XI Kurikulum 2013 khususnya untu siswa Madrasah Aliyah.

$\mathrm{KH}$. Masjkur merupakan tokoh asal Malang yang berlatar pendidikan sebagai santri namun mampu menunjukkan eksistensi dan perannya sebagai warga negara yang baik di lintas tiga jaman yaitu masa perjuangan kemerdekaan, Orde Lama dan Orde Baru. Perjuangan beliau diberbagai bidang seperti pendidikan, militer dan politik dapat dijadikan role model bagi siswa Madrasah Aliyah bahwa seorang santri mampu berkiprah di kancah nasional sesuai dengan kapasitasnya. Selain itu juga kisah kehidupan beliau dapat dijadikan sebagai teladan bahwa semakin memahami ilmu agama berarti semakin bijaksana dalam menyikapi berbagai masalah sosial termasuk perbedaan horisontal dalam masyarakat. Pemahaman akan hal ini diharapkan mampu memberikan bekal kepada siswa untuk menyikapi konflik-konflik atas nama agama di tengah klaim-klaim individu maupun kelompok yang menyatakan bahwa pendapat merekalah yang paling benar sedangkan kelompok lain salah.

JPSI, Vol. 1, No., 1, 2018 


\section{RUJUKAN}

Ayundasari, L.2018. KH. Masjkur dalam Sejarah Pendidikan Islam Modern di Indonesia 1923-1992. Malang: UM Press

Azra, A dan Umam,S. 1998. Menteri-menteri Agama RI: Biografi Sosial Politik. Jakarta: INIS Desmita. 2006. Psikologi Perkembangan. Bandung:PT. Remaja Rosda Karya

Hatimah, I.2009.Pembelajaran Berwawasan Kemasyarakatan. Jakarta: Universitas Terbuka

Hisyam, M. 2001. Caught between Three Fires. Jakarta: INIS

Kochhar, S.K.2008. "Teaching Of History. Jakarta: Grasindo

Mas'ud, AM. 2006. Dari Haramain ke Nusantara: Jejak Intelektual Arsitek Pesantren. Jakarta: Kencana

Zuchdi, D. 2008. Humanisasi Pendidikan. Jakarta: Bumi Aksara 